\title{
EFFECTIVENESS OF NATURAL SOIL CONDITIONERS AND IRRIGATION REGIME ON: \\ 1- LOAMY SAND SOIL PROPERTIES, CROPS PRODUCTION AND WATER PRODUCTIVITY
}

\author{
A.M.S. Kheir, M.A. Bayoumi and H.M.A. Abouelsoud \\ Soils, Water and Environ. Res. Inst., Agricultural Research Centre, Giza, Egypt \\ Received: May. 31, 2017 \\ Accepted: Jul. 2, 2017
}

\begin{abstract}
Two field experiments were carried out at loamy sand soil, located at Baltim district, Kafr El-Sheikh Governorate. The experiments were occupied for conducting wheat and maize during winter and summer seasons of 2015/2016 and 2016 respectively. The main objectives of this investigation were to study and evaluate the effect of soil conditioner types, and their mixtures in sandy soil subjected to different irrigation deficits on the following parameters: (i) soil properties (chemical, physical and moisture constants, and (ii) agronomical production of wheat and maize and water productivity after full maturity in the studied soil under consideration.

Four types of soil conditioners [bentonite, compost, polyacrylamide and their mixtures 1:1:1(w/w)] were applied before cultivation. Three levels of soil moisture depletion regimes were used (30, 50 and $70 \%)$ from its available water capacity. Applying natural soil conditioner types, and their mixtures in the studied sandy soil subjected to moisture depletion regime realized improving soil chemical, physical and moisture content. Soil salinity (soil reaction, electrical conductivity and ionic strength), hazard sodium parameters (soluble sodium percentage and sodium adsorption ratio), soil porosity and available water capacity were increased. On the other hand, hydraulic conductivity and bulk density were decreased. Polyacrylamide treatment realized the superiority under wheat and maize field experiments. Irrigation after $50 \%$ AWSMD gave moderate values of such properties between wet (30\% AWSMD) and dry (70\% AWSMD). Increasing grains, straw, grains weight and harvest index significantly for wheat and maize crops, because of adding soil conditioners compared with control. Results also indicated that, from view point of water and economic, the highest values of crop yield and water productivity were obtained from irrigation at $50 \%$ depletion from its available water capacity rather than 30 $\%$ and $70 \%$ respectively.
\end{abstract}

Key words: Sandy soils; Water productivity; Soil conditioners; Ionic strength; Wheat and maize.

\section{INTRODUCTION}

Nowadays, the term of " sustainable agriculture " is widely used globally, which is keystone of the rational utilization of soils as one of our most important natural resources. It is the important aims of "sustainable agriculture " to protect and maintain of the multi-functions of soils (Várallyay, 2005). For preservation and sustainability, the productivity of soil we should take special regard to sandy soils having unfavorable properties. Sandy soil characterized by less than $18 \%$ clay and more than $68 \%$ sand in the first $100 \mathrm{~cm}$ of the soil depth are the poor soils that occur in many parts of the world (Van Wambeke, 1992). There are other problems facing agriculture sector caused by, mainly, inappropriate soil, water and fertile management practices as well as rapid decreasing of agricultural land particularly in Delta soils. Therefore, we must find rapid solutions to face these problems. Sandy soils hold little water as the large pore spaces allow water to drain freely from soil. The productivity of these soils is limited by low water holding capacities, high 
infiltration rates, high evaporation, low inherent fertility levels, very low organic matter content and excessive deep percolation losses. Also, the water use efficiency of the crops cultivated in such soil is low.

Tackling these problems can be achieved through applying organic amendments and soil conditioners. These materials improve the retentive capacities of these soils and allow plants to get their water requirements and phyto -available nutrients easily. Use of polyacrylamides as soil conditioner in many countries increased after the introduction of Krilium in 1951 (De Boodt, 1972). New generation polyacrylamides have high molecular weights and require low application rates. They also have important environment, soil conservation and irrigation efficiency benefits for general agriculture, making their use economically feasible (Sojka and Lentz, 1994). The properties of different types of polyacrylamides have been described by (Bouranis, 1997). The effect of cross-linked polyacrylamides on physical and chemical properties of sandy soils has been described by (Al-Omran and Al-Harbi, 1997). The use of cross-linked polyacrylamides has been tested to increase the water holding capacity of sandy soils (Silberbush et al., 1993, Stewart, 1975, Taylor and Halfacre, 1986). Polyacrylamides in soil were also able to reduce the amount of water lost from the soil through evaporation (Al-Omran and Al-Harbi, 1997). Nevertheless, using this type of soil conditioner to amend Egyptian sandy soils is so far.

Bentonite - a rock containing mainly $2: 1$ clay mineral montmorillonite, a member of the smectite family - has been recognized in many countries as a very good amendment to improve the properties of such infertile sandy soils (BENKHELIFA et al., 2008), (SALETH et al., 2009, SATJE and NELSON, 2009)

Cereal crops such as (wheat and maize) are very strategically important crops in
Egypt because it's constituent and indispensable part of Egyptian food diet. Generally, there is a great gap between the consumption and production of such crops. On the other hand, it is worth noting that, the agriculture production in Egypt is mainly depend upon irrigated agriculture. The gap between supplies and demands of water is widening with increasing global population. Egypt suffering from this trouble, especially when we know that we are under water poverty limit. Because of the water limitation, one of the most important targets in the agriculture sector is how to save irrigation water and increase water use efficiencies. So, new techniques and practices are needed to achieve water save. Estimating irrigation water becomes important for project planning and irrigation management. The over irrigation practiced by the farmers usually leads to low irrigation efficiency. So, it is necessary to ascertain to what extent the water in the root zone can be depleted to produce high economic yield with using little water applied. Planning best irrigation regimes is very important for maintaining available irrigation water. The proper water management (irrigation scheduling) not only limits determination of crop water requirements but also helps to know when and how much water should be applied to get high efficiency of each unit of water. Regulated deficit irrigation is one of such practices. Many studies indicated that the deficit irrigation was a successful technique in crops irrigation, (Omran, 2005, Seif et al., 2005).

The main objectives of this investigation were to study and asses the effect of natural soil conditioner types and their mixtures in sandy soils subjected to irrigation regimes on:

(i): Soil physico-chemical properties and moisture constants.

(ii): Agronomical production of wheat and maize crops after full maturity.

(iii): Crop water productivity of both wheat and maize 


\section{MATERIALS AND METHODS 2.1. Experimental design, agronomic practices and soil analysis:}

A field experiment was conducted at Baltim district, Kafr El-Sheikh Governorate $31^{\circ} 3440.6 \mathrm{~N}$ latitude and $31^{\circ} 1055.5 \mathrm{E}$ longitude with an elevation of about 3 meters above sea levels. The experiment has been conducted for wheat and maize during winter and summer seasons of 2015 /2016 and 2016 respectively. Before planting and after wheat and maize plants full maturity, representative composite disturbed soil surface samples were collected, air dried, crumbled by hand, homogenized and finely ground in steel mill to pass through 100-mesh (0.15 mm opening sieve) and thoroughly mixed. Generally, soil chemical characterizations of the studied soils before cultivation and directly after cereal crops harvesting as well as properties of the used matured co-compost and irrigation water were performed using classical methods as reported and explained by (Burt, 2004, Cottenie et al., 1982) as tabulated in all Tables in this work. lonic strength (mmoles $\mathrm{L}^{-1}$ ): was calculated using the following equation as explained by (Tam, 1993).

lonic strength $\left(\mathrm{mmoles}^{-1}\right)=1 / 2 \sum_{\mathrm{i}=1}^{i=n} \mathrm{Mi}_{\mathrm{i}}^{2}$

Where: $M i=$ conc. of ion (i) in mmoles $\mathrm{L}^{-1}$ and $\mathrm{Zi}=$ charge of ion ( $\mathrm{i})$.

Additionally, undisturbed vertical cylindrical volumes of field-moist soil samples were gently obtained using cylindrical sharp edged core samplers for estimating soil physical properties and soil moisture constants using routine work analysis methods as reported and described by (Garcia, 1978, Klute, 1986) (Okalebo et al., 1993, Reynolds, 1993a, Reynolds, 1993b). Soil moisture constants (field capacity, permanent wilting point and available water capacity) were measured and calculated by means of pressure cooker and pressure membrane apparatus for measuring moisture contents at pressures of 0.33 and 15 bar. Bulk and particle (real) densities were estimated. Soil porosity in volume percent was calculated. Field saturated hydraulic conductivity in situ was determined using constant head well permeameter method employing Guelph permeameter apparatus. All soil obtained values were calculated on oven dry weight basis $105 \mathrm{C}^{\circ}$ for 24 hours. Soil physicochemical analysis and moisture constants for the studied soil before cultivation are shown in Tables (1 and 2) respectively. Chemical properties of irrigation water under consideration during the carrying out are listed in Table (3). The experimental plot area was $6.0 \mathrm{~m}^{2}(2 \times 3 \mathrm{~m})$. The experimental design was split-plot arrangement with three replications. The main plots were devoted to three irrigation treatments as follows: irrigation at 30,50 and $70 \%$ depletion from soil available water capacity. Wheat and maize plants were exposed to deficit irrigation and started directly after life watering irrigation (El-Mohayaa irrigation) for achieving the selected available soil moisture depletion levels under consideration. Detailed experimental obtained data about irrigation scheduling and the actual seasonal applied water for wheat and maize crops production cultivated in loamy sand soils subjected to soil moisture depletion regimes over the growing winter and summer season periods are tabulated in Tables (6 and 7). The sub plots were assigned to five types of soil conditioners and their mixtures 1:1:1(w/w). The conditioner treatments $(\mathrm{w} / \mathrm{w})$ were applied as follows: Control (without additions); Bentonite at application rate of $0.3 \%$, compost at application rate of $0.5 \%$, polyacrylamide at application rate of $0.3 \%$; and the mixtures of the three previous conditioners in 1:1:1 ratio at rate of $0.37 \%$. The soil conditioner treatments were randomly distributed in the three main plots. The application rates of such conditioners 
A.M.S. Kheir, et al.,

were based on the recommended doses as described by (El-Naka et al., 2015). They also detailed the physio-chemical analysis of analysis of compost had been done in Soil Improvement and Conservation Department, PAM and bentonite. Meanwhile, the detailed Sakha Agriculture Research Station.

Table (1): Initiative physico-chemical characteristics of the experimental site before planting

\begin{tabular}{|c|c|}
\hline Soil characters and units & Values \\
\hline \multicolumn{2}{|l|}{ Chemical analysis } \\
\hline Soil reaction $\mathrm{pH}$ (1:2.5 soil-water suspension) & 7.90 \\
\hline Electrical conductivity, Ec dSm$m^{-1}$ (soil past extract) at $25 \mathrm{C}^{\circ}$ & 2.75 \\
\hline Saturation percentage (S.P) & 40.0 \\
\hline Total soluble salts (T.S.S) & 1760 \\
\hline Calcium carbonate $\left(\mathrm{CaCO}_{3}\right)$ & 0.60 \\
\hline \multicolumn{2}{|l|}{ Total soluble ions (1:5 Soil-water extractions) } \\
\hline \multicolumn{2}{|l|}{ Soluble cations } \\
\hline$m e q L^{-1}$ & 1.00 \\
\hline$m e q L^{-1}$ & 1.20 \\
\hline$m e q \mathrm{~L}^{-1}$ & 3.70 \\
\hline$m e q \mathrm{~L}^{-1}$ & 0.10 \\
\hline \multicolumn{2}{|l|}{ Soluble anions } \\
\hline$m e q \mathrm{~L}^{-1}$ & 0.00 \\
\hline$m e q \mathrm{~L}^{-1}$ & 1.50 \\
\hline$m e q \mathrm{~L}^{-1}$ & 2.00 \\
\hline$m e q \mathrm{~L}^{-1}$ & 2.50 \\
\hline (1:5 soil-water extraction) & 0.602 \\
\hline Ionic strength (I.S) & 4.45 \\
\hline \multicolumn{2}{|l|}{ Physical analysis } \\
\hline Silt fraction & 31.0 \\
\hline Clay fraction & 13.5 \\
\hline Soil texture class & Loamy sand \\
\hline Soil bulk density(Pb) & 1.55 \\
\hline Soil particle density (Ps) & 2.66 \\
\hline Total porosity(E) on volume basis & 41.73 \\
\hline Soil saturated hydraulic conductivity (S.H.C) & 2.65 \\
\hline Soil cation exchange capacity $(C E C) \mathrm{cmolc} / \mathrm{kg}$ soil & 15 \\
\hline
\end{tabular}

Table (2): Soil moisture constants and its nutritional status of the experimental site before planting.

\begin{tabular}{|c|c|}
\hline Soil variables & Obtained values \\
\hline \multicolumn{2}{|c|}{ Soil moisture constants } \\
\hline Field capacity (S.F.C) & 18.0 \\
\hline Permanent wilting point (P.W.P) & 9.00 \\
\hline Available water capacity (A.W.C) & 9.00 \\
\hline \multicolumn{2}{|c|}{ Soil nutritional status } \\
\hline Total organic-C & 0.232 \\
\hline Organic matter (O.M) & 0.400 \\
\hline \multicolumn{2}{|c|}{ Available macro-nutrients } \\
\hline Available - N (K-sulphate extractable) $\mathrm{mgkg}^{-1}$ soil & 21.5 \\
\hline Available - $\mathrm{P}\left(\mathrm{NaHCO}_{3}\right.$ extractable $) \mathrm{mgkg}^{-1}$ soil & 8.90 \\
\hline Available $-\mathrm{K}\left(\mathrm{NH}_{4}\right.$-acetate extractable) $\mathrm{mgkg}^{-1}$ soi & 53.5 \\
\hline
\end{tabular}




\begin{tabular}{|ll|l|}
\hline \multicolumn{2}{|c|}{ Available micronutrients } \\
\hline Available - Fe(DTPA extractable) & $\mathrm{mgkg}^{-1}$ soil & 6.50 \\
\hline Available - Mn(DTPA extractable) & $\mathrm{mgkg}^{-1}$ soil & 5.00 \\
\hline Available-Zn(DTPA extractable) & $\mathrm{mgkg}^{-1}$ soil & 1.10 \\
\hline Available - Cu (DTPA extractable) & $\mathrm{mgkg}^{-1}$ soil & 0.66 \\
\hline
\end{tabular}

Table (3): Chemical analysis of irrigation water under consideration during the carrying out of field experimental periods.

\begin{tabular}{|c|c|c|c|c|c|c|c|c|c|c|c|c|c|c|c|}
\hline \multirow{2}{*}{ 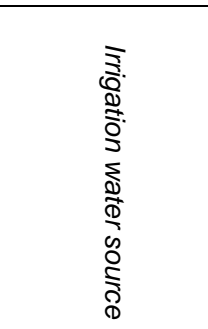 } & \multirow{2}{*}{$p H$} & \multirow[b]{2}{*}{$\begin{array}{l}0_{n} \\
\text { sn }_{i}\end{array}$} & \multicolumn{5}{|c|}{$\begin{array}{c}\text { Total soluble cations } \\
\text { meq } L^{-1}\end{array}$} & \multicolumn{2}{|c|}{$\begin{array}{c}\text { Sodium } \\
\text { hazard } \\
\text { parameters }\end{array}$} & \multicolumn{5}{|c|}{$\begin{array}{l}\text { Total soluble anions } \\
\text { meq } L^{-1}\end{array}$} & \multirow{2}{*}{ 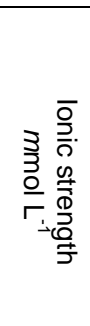 } \\
\hline & & & $\overbrace{+}$ & $\begin{array}{r}3 \\
\vdots \\
+\end{array}$ & $z_{+}$ & $\pi_{+}$ & 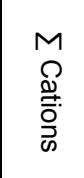 & D & $\begin{array}{l}\text { CD } \\
\text { T } \\
\circ\end{array}$ & ○్థ & ○ & $\underline{\Omega}$ & D & $\begin{array}{l}M \\
\text { M } \\
\text { 产. } \\
\text { क }\end{array}$ & \\
\hline $\begin{array}{c}\text { El-Gharbia main } \\
\text { drain (Cotchner) } \\
\text { (at Abou Omera } \\
\text { east village, } \\
\text { Baltim district ) }\end{array}$ & 7.94 & 1.52 & 3.5 & 2.3 & 9.2 & 0.15 & 15.15 & 5.76 & 60.73 & 0.0 & 5.1 & 7.1 & 3.0 & 15.2 & 18.075 \\
\hline
\end{tabular}

These conditioner types are mixed well with soil and incorporated into soil surface before plowing during soil service process and its preparation before planting. The chemical analysis of these conditioners is listed in Tables (4,5 and 6) for bentonite, compost and polyacrylamide respectively. Seeds of wheat plants (Triticum aestivum, Misr1 variety) were obtained from Crop Agronomy Research Department, Sakha Agriculture Research Station and sown on November11,2015. Grains of maize plants (Zea mays, $L$ ) three cross 321 variety were obtained from Maize Research Center, Agriculture Research Center and sown on May,15,2016. Aerobic / Thermophilic cocomposting process was carried out at the experimental farm of Soil Improvement and Conservation Research Department, Sakha Agriculture Research Station before beginning of the winter growing season elongated five months from May 2015 to October 2015. Pyramidical piles (heaps) 2.5 $\times 2.5 \times 1.5 \mathrm{~m}$ was built up under aerobic conditions. Different solid bio-wastes were used as substrates and augmented organically with farmyard manure (10\% $\mathrm{w} / \mathrm{w})$ as microbial organic activator as well as with urea, super phosphate and potassium sulfate as microbial chemical activators. The other certain additional materials were incorporated into for speeding up the conversion and improving the final product quality and as growth promoting substances, $\mathrm{pH}$ buffering agents and as bulking agents. The obtained chemical and physical characteristics of the used matured co-compost after cocomposting process are listed in Table (5). This matured co-compost was used as soil conditioner.

\subsection{Irrigation water supply and calculations:}

Irrigation water supply and number of irrigations were limited per the levels of soil moisture depletion regimes. Consequently, soil moisture content at demand depletion levels determines the timing of irrigation. Soil moisture content directly before irrigation at which calculated applied water must be added immediately for arriving at soil field capacity was measured in situ using TDR apparatus (Time Domain Reflectometer). The magnitude of planting and life watering irrigates were measured and applied using cutthroat flume $(20 \times 90 \mathrm{~cm})$ according to (Early, 1975). Magnitude of irrigation applied water were calculated using the 
A.M.S. Kheir, et al.,

following soil moisture depletion equation as reported by (Israelson and Hansen, 1962) during wheat and maize growing season periods.

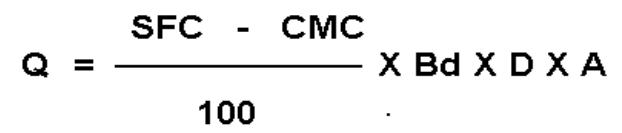

Where: $\mathrm{Q}=$ Quantity of applied water $\mathrm{m}^{3}$ plot $^{-1}$ /irrigate; SFC = Soil field capacity (\%) in percent by volume; $\mathrm{CMC}=$ Soil moisture content just before irrigation using TDR apparatus; $\mathrm{Bd}=$ Soil bulk density $\mathrm{Mg} \mathrm{m}^{-3}$; D = Soil depth $(\mathrm{m})$, effective root depth or soil depth required to be irrigated; and $A=$ plot experimental area $\left(\mathrm{m}^{2}\right)$ that would be irrigated.

Total irrigation water applied for wheat and maize crops subjected to the required irrigation regime is detailed in Tables (7\&8). Water productivity was calculated as the weight of marketable crop production per the volume unit of applied irrigation where expressed as cubic meter of water.

Wheat crop was harvested on 25 from March, while maize crop was harvested on 30 of August.

Table (4): Chemical and mineralogical analysis of the used bentonite.

\begin{tabular}{|c|c|}
\hline Characteristics & Values \\
\hline \multicolumn{2}{|c|}{ Elemental oxides: \% } \\
\hline $\mathrm{SiO}_{2}$ & 55.9 \\
\hline $\mathrm{TiO}_{2}$ & 0.20 \\
\hline $\mathrm{Al}_{2} \mathrm{O}_{3}$ & 20.0 \\
\hline $\mathrm{Fe}_{2} \mathrm{O}_{3}$ & 0.70 \\
\hline $\mathrm{MnO}$ & 0.001 \\
\hline $\mathrm{MgO}$ & 0.65 \\
\hline $\mathrm{CaO}$ & 2.70 \\
\hline $\mathrm{Na}_{2} \mathrm{O}$ & 1.76 \\
\hline $\mathrm{K}_{2} \mathrm{O}$ & 2.40 \\
\hline $\mathrm{P}_{2} \mathrm{O}_{5}$ & 0.80 \\
\hline $\mathrm{SO}_{3}$ & - \\
\hline Loss on ignition & 10.0 \\
\hline $\mathrm{Ec}_{\mathrm{e}} \mathrm{dS} m^{-1}(1: 10$ Bentonite-water extract(w/v) & 1.82 \\
\hline $\mathrm{pH}(1: 2.5$ bentonite-water suspension $(\mathrm{w} / \mathrm{v})$ & 7.12 \\
\hline \multicolumn{2}{|c|}{ Total soluble cations $\left(m^{2} \mathrm{~L}^{-1}\right)(1: 5$ extracts $)$} \\
\hline $\mathrm{Ca}^{+2}$ & 0.79 \\
\hline $\mathrm{Mg}^{+2}$ & 0.27 \\
\hline $\mathrm{Na}^{+}$ & 1.95 \\
\hline $\mathrm{K}^{+}$ & 0.02 \\
\hline \multicolumn{2}{|c|}{ Total soluble anions (meq $\left.\mathrm{L}^{-1}\right)(1: 5$ extracts) } \\
\hline $\mathrm{CO}_{3}{ }^{=}$ & - \\
\hline $\mathrm{HCO}_{3}^{-}$ & 0.24 \\
\hline $\mathrm{Cl}^{-}$ & 1.59 \\
\hline $\mathrm{SO}_{4}=$ & 1.06 \\
\hline Cation exchange capacity, cmoles $\mathrm{kg}^{-1}$ & 59.13 \\
\hline
\end{tabular}


Effectiveness of natural soil conditioners and irrigation regime on:

\begin{tabular}{|c|c|}
\hline Calcium carbonate $\%$ & 14.27 \\
\hline \multicolumn{2}{|l|}{ Particle size distribution $\%$} \\
\hline Clay fraction & 85.75 \\
\hline Silt fraction & 10.54 \\
\hline Sand fraction & 3.71 \\
\hline \multicolumn{2}{|l|}{ Table (5): The detailed analysis of the used compost } \\
\hline Characteristics & Values \\
\hline Dry weight $\left(\mathrm{kg} \mathrm{m}^{-3}\right)$ & 650.0 \\
\hline Moisture content (\%) & 25.5 \\
\hline Odor and color & Acceptable and dark \\
\hline $\mathrm{pH}(1: 10$ compost-water suspension $\mathrm{w} / \mathrm{v})$ & 7.16 \\
\hline EC $(1: 10$ compost - water extraction $w / v)$ & 5.23 \\
\hline Total soluble salts (soil paste -water extraction 1:10) \% & 0.335 \\
\hline Saturation percentage \% $(\mathrm{g} / 100 \mathrm{~g}$ & 175.0 \\
\hline Total soluble salts (compost material) \% (g/100g compost) & 0.586 \\
\hline CEC $\left(\mathrm{cmole} \mathrm{kg}^{-1}\right)$ & 64.34 \\
\hline Total organic - c \% & 25.5 \\
\hline Total organic matter \% & 43.96 \\
\hline $\mathrm{C} / \mathrm{N}$ ratio & 21.98 \\
\hline \multicolumn{2}{|l|}{ Total macro-nutrients \% } \\
\hline Total-nitrogen $\%$ & 1.16 \\
\hline Total - phosphorus \% & 0.53 \\
\hline Total - potassium \% & 0.37 \\
\hline \multicolumn{2}{|c|}{ Available macro-nutrients ( $m \mathrm{~g} \mathrm{~kg}$ compost) } \\
\hline Available - N (potassium sulfate) & 100 \\
\hline Available - $\mathrm{P}\left(0.5 \mathrm{M} \mathrm{NaHCO}_{3^{-}} \mathrm{pH} 8.5\right)$ & 50 \\
\hline Available - K (ammonium acetate $\mathrm{pH} 7)$ & 85 \\
\hline \multicolumn{2}{|c|}{ Available micro-nutrients ( $m g \mathrm{~kg}$ compost) } \\
\hline Available - Fe & 450 \\
\hline Available $-\mathrm{Mn}$ & 100 \\
\hline Available - Zn & 35 \\
\hline Available - Cu & 135 \\
\hline \multicolumn{2}{|c|}{ Total micro-nutrients ( $\mathrm{mg} \mathrm{kg}$ compost) } \\
\hline Total -Fe & 753 \\
\hline Total $-\mathrm{Mn}$ & 361 \\
\hline Total $-\mathrm{Zn}$ & 297 \\
\hline Total - Cu & 168 \\
\hline \multicolumn{2}{|c|}{ Available heavy metals ( $\mathrm{mg} \mathrm{kg} \mathrm{compost)}$} \\
\hline Available - Cd & 13.2 \\
\hline Available - Ni & 62.7 \\
\hline Available $-\mathrm{Pb}$ & 120 \\
\hline
\end{tabular}

Table (6): Physicochemical properties of the anionic polyacrylamide (PAM).

Characteristics

Viscosimetry molecular weight $(\mathrm{g} / \mathrm{mol})$

$\mathrm{pH}$

Total carbon (\%)

Values

104758.9

Total nitrogen (\%)

$\mathrm{C} / \mathrm{N}$

Molar volume $(\mathrm{mL} \mathrm{mol}$

7.4

42.2

16.2

2.6

54.6 





Effectiveness of natural soil conditioners and irrigation regime on:

\begin{tabular}{|l|l|}
\hline Molecular weight $\left(\mathrm{g} \mathrm{mol}^{-1}\right)$ & 71.08 \\
\hline Van-der-Waals volume $\left(\mathrm{ml} \mathrm{mol}^{-1}\right)$ & 38.6 \\
\hline Water solubility & Soluble \\
\hline Melting point & $>3$ \\
& 00 \\
& ${ }^{\circ} \mathrm{C}$ \\
\hline Retention & $\begin{array}{l}\text { High } \\
\end{array}$ \\
\hline Toxicity & retention \\
\hline
\end{tabular}




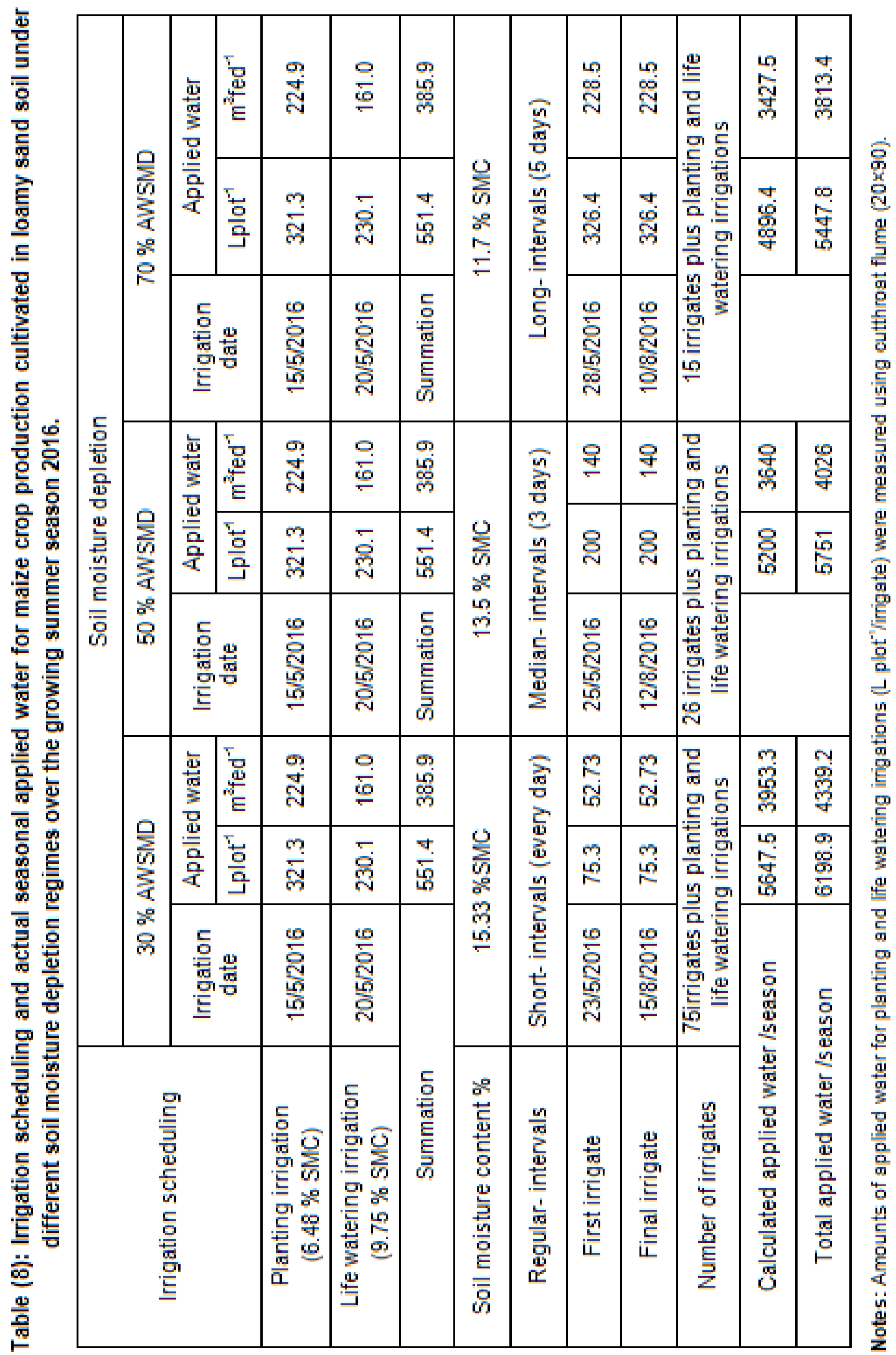




\subsection{Statistical analysis:}

Analysis of variance was done according to (Snedecer and Cochran, 1976) using the Irristat software, version 4.1 according to Biometrics Unit,1998, (IRRI, 1998).

\section{RESULTS AND DISCUSSION}

\subsection{Soil chemical properties in response to adding soil conditioners}

Concerning the effect of applying natural soil conditioner types and their mixtures (1:1:1) in loamy sand soils subjected to soil moisture depletion regimes (30\%, $50 \%$ and $70 \%$ ) from their available water capacities after wheat and maize crops harvesting on soil salinity $\mathrm{pH}, \mathrm{EC}$ (dS m ${ }^{-}$ ${ }^{1}$ ), and ionic strength mmole $\mathrm{L}^{-1}$ and hazard sodium parameters (SAR and SSP \%) are listed in Tables (9.1 and 9.2). Generally, the analytical chemicals results listed in after mentioned tables illustrate that values of these chemical parameters in the studied soil on the average of other studied parameters (irrigation treatments) were markedly increased due to the application of soil conditioner types in comparison with control values (without additions). These increases could be arranged in the following descending order as follow: mixtures $(1: 1: 1)>$ polyacrylamide> bentonite > compost > control. The highest values were achieved because of mixtures application, meanwhile, the lowest values were obtained by dressing the compost treatment. Increasing the values of chemical parameters for soil after conditioner applications is mainly attributed to the initial analysis of these conditioners.

On the other hand, these studied chemical properties, on the average of the other studied parameters (conditioner types), were markedly increased with increasing the depletion regimes from its soil available water capacity. Where, the highest values of these chemical parameters were achieved under dry treatment (70 \% AWSMD), meanwhile, the lowest values were recorded under wet treatment (30\% AWSMD). Medium treatment had the moderate values between wet and dry treatments. The analytical obtained increments could be rearranged in the following ascending order: wet -treatment (30\% AWSMD) < medium - treatment $(50 \%$ AWSMD) $<$ dry - treatment (70 \% AWSMD). This could be attributed to the dilution effect, since, salt concentration was decreased with increasing irrigation applied water. Data listed in Table (9.2) reveal also that under maize experiment, the studied chemical properties were increased with adding soil conditioner types and their mixtures $(1: 1: 1)$ on the overall average of the other studied parameters (irrigation treatments) in comparison with their control -values (without additions) at the same conditions. These parameters mannered the following descending order: mixtures $(1: 1: 1)>$ polyacrylamide $>$ bentonite $>$ compost $>$ control. Generally, the obtained values of chemical properties after wheat crop harvesting were lower than those obtained after maize crop harvesting. This mainly attributed to residual effects of conditioners remained from winter season as a doubling effect with the new added doses in summer season.

\subsection{Soil physical properties:}

The results collected in Tables (10.1\&10.2) show that, on average of other studied parameters (irrigation treatments), that saturated hydraulic conductivity SHC (m day ${ }^{-1}$ ) and bulk density $\mathrm{Db}\left(\mathrm{Mg} \mathrm{m}^{-3}\right)$ were markedly decreased as a result of adding soil conditioner types and their mixtures (1:1:1) in the studied soil after wheat crop harvesting in comparison with their control values. The magnitude of these decrements which less the control values were depended upon the types of these conditioners. It is clearly that; the lowest values were achieved and accompanied with applying polyacrylamid treatment. Meanwhile, the highest values were obtained with the dressing compost conditioner in comparison with their control values. These decrements could be arranged in the following descending order as follows: polyacrylamide $>$ mix of all $>$ bentonite $>$ 




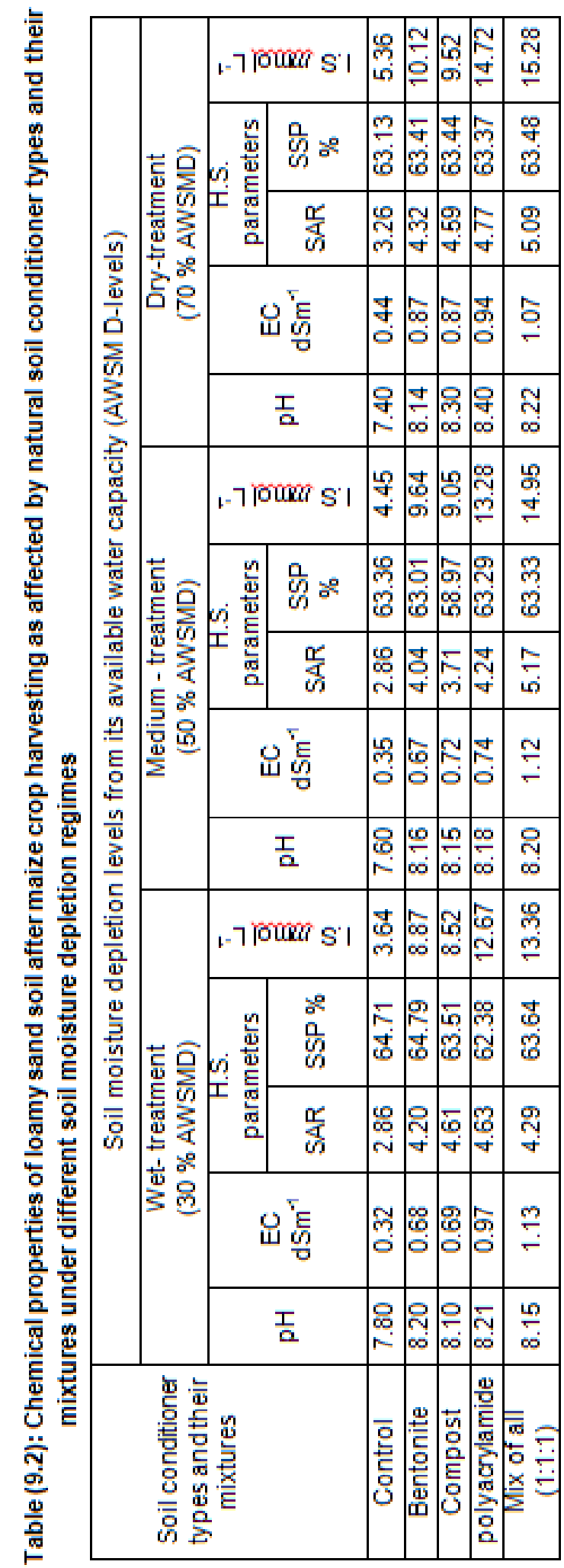


Table (10.1): Saturated hydraulic conductivity, bulk density and total porosity of studied soils after wheat crop harvesting as affected by natural soil conditioner types and their mixtures under different soil moisture depletion regimes.

\begin{tabular}{|c|c|c|c|c|c|c|c|c|c|}
\hline \multirow{3}{*}{$\begin{array}{l}\text { Soil conditioner } \\
\text { types and their } \\
\text { mixtures }\end{array}$} & \multicolumn{9}{|c|}{$\begin{array}{l}\text { Soil moisture depletion levels from its available water capacity } \\
\text { ( AWSMD-levels) }\end{array}$} \\
\hline & \multicolumn{3}{|c|}{$\begin{array}{l}\text { Wet - treatment } \\
(30 \% \text { AWSMD) }\end{array}$} & \multicolumn{3}{|c|}{$\begin{array}{l}\text { Medium - treatment } \\
\quad(50 \% \text { AWSMD) }\end{array}$} & \multicolumn{3}{|c|}{$\begin{array}{l}\text { Dry -treatment } \\
(70 \% \text { AWSMD) }\end{array}$} \\
\hline & $\begin{array}{l}\text { SHC } \\
\text { (m/day) }\end{array}$ & $\begin{array}{c}\mathrm{D}_{\mathrm{b}} \\
(\mathrm{Mg} \\
\left./ \mathrm{m}^{3}\right) \\
\end{array}$ & $\begin{array}{c}\rho_{\mathrm{T}} \\
(\%)\end{array}$ & $\begin{array}{l}\mathrm{SHC} \\
\text { (m/day) }\end{array}$ & $\left(\begin{array}{c}D_{b} \\
\left(M g / m^{3}\right.\end{array}\right.$ & $\begin{array}{c}\rho_{\mathrm{T}} \\
(\%)\end{array}$ & $\begin{array}{l}\mathrm{SHC} \\
\text { (m/day) }\end{array}$ & $\begin{array}{c}\mathrm{D}_{\mathrm{b}} \\
(\mathrm{Mg} \\
\left./ \mathrm{m}^{3}\right) \\
\end{array}$ & $\begin{array}{l}\rho_{\mathrm{T}} \\
(\%)\end{array}$ \\
\hline Control & 2.48 & 1.55 & 41.51 & 2.54 & 1.56 & 41.13 & 2.47 & 1.57 & 40.7 \\
\hline Bentonite & 2.41 & 1.45 & 45.28 & 2.40 & 1.41 & 46.79 & 2.43 & 1.40 & 47.17 \\
\hline Compost & 2.43 & 1.45 & 45.28 & 2.43 & 1.42 & 46.42 & 2.53 & 1.30 & 50.94 \\
\hline Polyacrylamide & 2.32 & 1.34 & 49.43 & 2.34 & 1.31 & 50.57 & 2.39 & 1.32 & 50.19 \\
\hline $\begin{array}{c}\text { Mix of all } \\
(1: 1: 1)\end{array}$ & 2.38 & 1.43 & 46.00 & 2.36 & 1.40 & 47.17 & 2.37 & 1.35 & 49.06 \\
\hline
\end{tabular}

Table (10.2): Saturated hydraulic conductivity, bulk density and total porosity of studied soils after maize crop harvesting as affected by natural soil conditioner types and their mixtures under different soil moisture depletion regimes.

\begin{tabular}{|c|c|c|c|c|c|c|c|c|c|}
\hline \multirow{3}{*}{$\begin{array}{l}\text { Soil conditioner } \\
\text { types and their } \\
\text { mixtures }\end{array}$} & \multicolumn{9}{|c|}{$\begin{array}{l}\text { Soil moisture depletion levels from its available water capacity (AWSMD- } \\
\text { levels) }\end{array}$} \\
\hline & \multicolumn{3}{|c|}{$\begin{array}{l}\text { Wet - treatment } \\
(30 \% \text { AWSMD) }\end{array}$} & \multicolumn{3}{|c|}{$\begin{array}{l}\text { Medium - treatment } \\
(50 \% \text { AWSMD) }\end{array}$} & \multicolumn{3}{|c|}{$\begin{array}{l}\text { Dry -treatment } \\
(70 \% \text { AWSMD) }\end{array}$} \\
\hline & $\begin{array}{l}\mathrm{SHC} \\
\text { (m/day) }\end{array}$ & $\begin{array}{c}D_{b} \\
\left(M g / m^{3}\right)\end{array}$ & $\begin{array}{l}\rho_{\mathrm{T}} \\
(\%)\end{array}$ & $\begin{array}{l}\mathrm{SHC} \\
\text { (m/day) }\end{array}$ & $\begin{array}{c}D_{b} \\
\left(M g / \mathrm{m}^{3}\right)\end{array}$ & $\begin{array}{c}\rho_{\mathrm{T}} \\
(\%)\end{array}$ & $\begin{array}{l}\mathrm{SHC} \\
\text { (m/day) }\end{array}$ & $\begin{array}{l}\mathrm{D}_{\mathrm{b}} \\
(\mathrm{Mg} \\
\left./ \mathrm{m}^{3}\right)\end{array}$ & $\begin{array}{l}\rho_{\mathrm{T}} \\
(\%)\end{array}$ \\
\hline Control & 2.63 & 1.50 & 43.40 & 2.60 & 1.48 & 44.15 & 2.55 & 1.52 & 42.64 \\
\hline Bentonite & 2.32 & 1.34 & 49.80 & 2.31 & 1.30 & 50.94 & 2.40 & 1.22 & 53.96 \\
\hline Compost & 2.42 & 1.35 & 49.06 & 2.32 & 1.30 & 50.94 & 3.17 & 1.28 & 51.70 \\
\hline Polyacrylamide & 2.20 & 1.32 & 49.43 & 2.48 & 1.40 & 47.17 & 3.10 & 1.30 & 50.94 \\
\hline $\begin{array}{c}\text { Mix of all } \\
(1: 1: 1)\end{array}$ & 2.34 & 1.33 & 48.30 & 2.35 & 1.35 & 49.06 & 2.00 & 1.32 & 50.19 \\
\hline
\end{tabular}

Table 9 compost > control. Oppositely, soil porosity values were mannered the opposite trend, where such values were increased over the control -values with adding soil conditioners and had the following sequence: polyacrylamide $<\operatorname{mix}$ of all < bentonite < compost < control. On the other hand, it was clearly apparent that, SHC values were gradually increased with increasing water irrigation deficits. However, $\mathrm{Db}$ and $\rho \mathrm{T}$ had the opposite trend, which decreased with increasing soil moisture depletion levels for its available water capacity. SHC - increments as well as $\mathrm{Db}$ and $\rho$ т decrements with increasing moisture depletion levels could be arranged in the following descending order as follows: wet treatment $(30 \%$ AWSMD) $>$ medium treatment $(50 \%$ AWSMD $)>$ dry - treatment (70\% AWSMD).

\subsection{Soil moisture constants:}

As concerns, field capacity (SFC \%), permanent wilting (PWP \%) and available water capacity (AWC\%) values of the studied loamy sand soils which reflect their 
A.M.S. Kheir, et al.,

soil water holding capacity after wheat and maize crops harvesting as affected by soil conditioner types and their mixtures under soil moisture depletion regimes, are presented in Tables (11.1 and 11.2) respectively. The obtained results, demonstrate that, on average of the other studied parameters (irrigation treatments), these soil moisture constants were obviously increased by applying soil conditioners and their mixtures $(1: 1: 1)$ in comparison with their control values at the same conditions. Generally, these increments over the controls in studied soil after wheat crop harvesting could be arranged in the following sequence as follows: polyacrylamide > mix of all >bentonite > compost > control. Soil water holding capacity parameters in summer season were higher than those in winter season, due to the residual effects of conditioners remained from winter season. Where the conditioners were added twice, the first time was before wheat cultivation and the second application was before maize cultivation with the same rates and in the same field as well. Analytical results show that application of polyacrylamide show its superiority over all other conditioner types under wheat and maize experiments. This is because, it is highly water-absorbent, forming a soft gel when hydrated. This function gives this conditioner the capacity to hold much water as compared with other soil conditioners.

Table (11.1): Field capacity, permanent wilting point and available water capacity of studied soils after wheat crop harvesting as affected by natural soil conditioner types and their mixtures under different soil moisture depletion regimes.

\begin{tabular}{|c|c|c|c|c|c|c|c|c|c|}
\hline \multirow{2}{*}{$\begin{array}{c}\text { Soil conditioner } \\
\text { types and their } \\
\text { mixtures }\end{array}$} & \multicolumn{3}{|c|}{ Soil moisture depletion levels from its available water capacity (AWSMD- } \\
& \multicolumn{3}{|c|}{$\begin{array}{c}\text { Wet- treatment } \\
(30\end{array}$} & \multicolumn{3}{c|}{$\begin{array}{c}\text { Medium - treatment } \\
(50 \% \text { AWSMD }\end{array}$} & \multicolumn{3}{c|}{$\begin{array}{c}\text { Dry - treatment } \\
(70 \% \text { AWSM }\end{array}$} \\
\cline { 2 - 10 } & $\begin{array}{c}\text { SFC } \\
(\%)\end{array}$ & $\begin{array}{c}\text { PWP } \\
(\%)\end{array}$ & $\begin{array}{c}\text { AWC } \\
(\%)\end{array}$ & $\begin{array}{c}\text { SFC } \\
(\%)\end{array}$ & $\begin{array}{c}\text { PWP } \\
(\%)\end{array}$ & $\begin{array}{c}\text { AWC } \\
(\%)\end{array}$ & $\begin{array}{c}\text { SFC } \\
(\%)\end{array}$ & $\begin{array}{c}\text { PWP } \\
(\%)\end{array}$ & $\begin{array}{c}\text { AWC } \\
(\%)\end{array}$ \\
\hline Control & 18.0 & 9.0 & 9.0 & 17.8 & 9.2 & 8.6 & 17.9 & 8.8 & 9.1 \\
\hline Bentonite & 18.9 & 9.5 & 9.4 & 18.8 & 9.6 & 9.2 & 19.8 & 9.2 & 10.6 \\
\hline Compost & 18.7 & 9.4 & 9.3 & 18.3 & 9.4 & 8.9 & 19.5 & 9.0 & 10.5 \\
\hline Polyacrylamide & 19.7 & 10.0 & 9.7 & 20.3 & 10.4 & 9.9 & 20.5 & 10.3 & 10.2 \\
\hline $\begin{array}{c}\text { Mix of all } \\
(1: 1: 1)\end{array}$ & 19.5 & 9.8 & 9.7 & 19.7 & 10.0 & 9.7 & 20.2 & 10.2 & 10.0 \\
\hline
\end{tabular}

Table (11.2): Field capacity, permanent wilting point and available water capacity of studied soils after maize crop harvesting as affected by natural soil conditioner types and their mixtures under different soil moisture depletion regimes.

\begin{tabular}{|c|c|c|c|c|c|c|c|c|c|}
\hline \multirow{3}{*}{$\begin{array}{l}\text { Soil conditioner } \\
\text { types and their } \\
\text { mixtures }\end{array}$} & \multicolumn{9}{|c|}{$\begin{array}{l}\text { Soil moisture depletion levels from its available water capacity (AWSMD- } \\
\text { levels) }\end{array}$} \\
\hline & \multicolumn{3}{|c|}{$\begin{array}{l}\text { Wet- treatment } \\
(30 \% \text { AWSMD) }\end{array}$} & \multicolumn{3}{|c|}{$\begin{array}{l}\text { Medium - treatment } \\
(50 \% \text { AWSMD) }\end{array}$} & \multicolumn{3}{|c|}{$\begin{array}{l}\text { Dry - treatment } \\
(70 \% \text { AWSMD) }\end{array}$} \\
\hline & SFC \% & $\begin{array}{c}\text { PWP } \\
\%\end{array}$ & $\begin{array}{c}\text { AWC } \\
\%\end{array}$ & SFC \% & $\begin{array}{c}\text { PWP } \\
\%\end{array}$ & AWC\% & SFC \% & $\begin{array}{c}\text { PWP } \\
\%\end{array}$ & AWC\% \\
\hline Control & 17.0 & 8.5 & 8.5 & 16.6 & 8.2 & 8.4 & 16.4 & 8.2 & 8.2 \\
\hline Bentonite & 18.4 & 9.0 & 9.4 & 17.8 & 8.8 & 9.0 & 17.3 & 8.5 & 8.8 \\
\hline
\end{tabular}


Effectiveness of natural soil conditioners and irrigation regime on:

\begin{tabular}{|c|c|c|c|c|c|c|c|c|c|}
\hline Compost & 18.1 & 8.8 & 9.3 & 18.5 & 8.9 & 9.6 & 17.5 & 8.8 & 8.7 \\
\hline Polyacrylamide & 20.4 & 10.0 & 10.4 & 19.4 & 9.7 & 9.7 & 19.0 & 9.4 & 9.6 \\
\hline $\begin{array}{c}\text { Mix of all } \\
(1: 1: 1)\end{array}$ & 19.5 & 9.8 & 9.7 & 18.7 & 9.3 & 9.4 & 18.2 & 9.0 & 9.2 \\
\hline
\end{tabular}

\subsection{Grain and straw yield of wheat and maize crops:}

Data listed in Tables (12.1, 12.2 and 12.3) demonstrate, on average other studied parameters (irrigation treatments), that application of soil conditioner types and their mixtures (1:1:1) resulted in significantly increasing wheat and maize grain yield, thousand grains weight, harvesting index and straw yield in comparison with their control values at the same conditions. The increments of these agronomical traits could be arranged in the following descending order as: polyacrylamide > mixtures $(1: 1: 1)>$ bentonite $>$ compost $>$ control. This mainly due to the ability of PAM in holding water rather than other conditioners. Where the retention properties of PAM are better than those in other types of conditioners. So, the highest values of these agronomical features in studied sandy soils were achieved and accompanied by applying conditioner - PAM treatment under both crops. However, the analytical obtained data, on average of the other studied parameters (conditioner treatments) reveal that all agronomical features except for harvest index were gradually decreased with increasing soil moisture depletion levels from its available water capacity. The magnitude of these decrements could be arranged in the following descending order as: wet-treatment $(30 \%$ AWSMD) $>$ medium -treatment (50\% AWSMD) > dry -treatment (70 \% AWSMD). However, harvest index (\%) was slightly increased with increasing irrigation deficits. Therefore, these increments could be arranged in the following sequence as: dry -treatment $(70 \%$ AWSMD) > medium -treatment (50\% AWSMD) > wet-treatment ( $30 \%$ AWSMD).

Generally, mean values of these parameters under medium treatment were higher than those obtained under wet and dry treatments and behaved the following order: medium $>$ wet $>$ dry. Such results were obtained by (Abdel-Rheem and Hassan, 2011), they found that the highest values of wheat water productivity and yield were achieved when irrigation at $50 \%$ depletion from available water, compared to $70 \%$ and $40 \%$ depletion in the loamy soils. confirming this conclusion, similar responses of maize crop production under field conditions was also reported by (Khalifa, 2013) who stated that, irrigation at $50 \%$ SMD gave the highest values of yield and its components of maize crop.

Table (12.1): Grains and straw yields of wheat and maize crops after full maturity as affected by natural soil conditioner types and their mixtures under $\mathbf{3 0} \%$ SMD.

\begin{tabular}{|c|c|c|c|c|c|c|c|c|}
\hline \multirow{3}{*}{$\begin{array}{c}\text { Soil } \\
\text { conditioner } \\
\text { types and their } \\
\text { mixtures }\end{array}$} & \multicolumn{4}{|c|}{ Wheat crop yield } & \multicolumn{4}{|c|}{ Maize crop yield } \\
\hline & $\begin{array}{l}\text { Grains } \\
\text { yield }\end{array}$ & $\begin{array}{c}1000 \\
\text { grains }\end{array}$ & $\stackrel{I}{I}$ & $\begin{array}{l}\text { Straw } \\
\text { yield }\end{array}$ & $\begin{array}{l}\text { Grains } \\
\text { yield }\end{array}$ & $\begin{array}{c}100 \\
\text { grains }\end{array}$ & $\underline{I}$ & $\begin{array}{l}\text { Straw } \\
\text { yield }\end{array}$ \\
\hline & $\left(\mathrm{kg} \mathrm{fed}^{-1}\right)$ & $(\mathrm{gm})$ & & $\left(\mathrm{kg} \mathrm{fed}^{-1}\right)$ & $\left(\mathrm{kg} \mathrm{fed}^{-1}\right)$ & (gm) & & $\begin{array}{c}(\mathrm{kg} \\
\left.\mathrm{fed}^{-1}\right)\end{array}$ \\
\hline Control & 1276.5 & 30.5 & 30.75 & 2875 & 1820 & 40.6 & 47 & 2053 \\
\hline Bentonite & 1749.8 & 40.65 & 37.25 & 2953 & 2875 & 43.45 & 49.19 & 2970 \\
\hline
\end{tabular}


A.M.S. Kheir, et al.,

\begin{tabular}{|c|c|c|c|c|c|c|c|c|}
\hline Compost & 1600.5 & 40.35 & 35.61 & 2888 & 2728 & 42.65 & 48.45 & 2903 \\
\hline Polyacrylamide & 2218.6 & 45.35 & 39.47 & 3403 & 2946 & 44.85 & 44.77 & 3635 \\
\hline $\begin{array}{c}\text { Mix of all } \\
(1: 1: 1)\end{array}$ & 2020.6 & 43.05 & 39.26 & 3115 & 2926 & 44.10 & 45.94 & 3444 \\
\hline
\end{tabular}

Table (12.2): Grains and straw yields of wheat and maize crops after full maturity as affected by natural soil conditioner types and their mixtures under $50 \%$ SMD.

\begin{tabular}{|c|c|c|c|c|c|c|c|c|}
\hline \multirow{3}{*}{$\begin{array}{c}\text { Soil } \\
\text { conditioner } \\
\text { types and their } \\
\text { mixtures }\end{array}$} & \multicolumn{4}{|c|}{ Wheat crop yield } & \multicolumn{4}{|c|}{ Maize crop yield } \\
\hline & $\begin{array}{l}\text { Grains } \\
\text { yield }\end{array}$ & $\begin{array}{c}1000 \\
\text { grains }\end{array}$ & $\stackrel{I}{=}$ & $\begin{array}{l}\text { Straw } \\
\text { yield }\end{array}$ & $\begin{array}{l}\text { Grains } \\
\text { yield }\end{array}$ & $\begin{array}{c}100 \\
\text { grains }\end{array}$ & I & $\begin{array}{l}\text { Straw } \\
\text { yield }\end{array}$ \\
\hline & $\left(\mathrm{kg} \mathrm{fed}^{-1}\right)$ & (am) & & $\left(\mathrm{kg} \mathrm{fed}^{-1}\right)$ & $\left(\mathrm{kg} \mathrm{fed}^{-1}\right)$ & (gr & & $\begin{array}{c}(\mathrm{kg} \\
\left.\mathrm{fed}^{-1}\right)\end{array}$ \\
\hline Control & 1302 & 30.6 & 32.69 & 2680 & 1977 & 41.2 & 42.46 & 2676 \\
\hline Bentonite & 1732.5 & 40.4 & 37.07 & 2935 & 2945 & 44.2 & 47.14 & 3318 \\
\hline Compost & 1578 & 40.1 & 35.82 & 2823 & 2846 & 43.05 & 49.19 & 2940 \\
\hline Polyacrylamide & 2017.5 & 44.4 & 39.77 & 3055 & 3051 & 43.7 & 44.26 & 3827 \\
\hline $\begin{array}{c}\text { Mix of all } \\
(1: 1: 1)\end{array}$ & 1950 & 42.5 & 39.57 & 2969 & 3037 & 44.75 & 44.86 & 3776 \\
\hline
\end{tabular}

Table (12.3): Grains and straw yields of wheat and maize crops after full maturity as affected by natural soil conditioner types and their mixtures under $70 \%$ SMD.

\begin{tabular}{|c|c|c|c|c|c|c|c|c|}
\hline \multirow{3}{*}{$\begin{array}{c}\text { Soil } \\
\text { conditioner } \\
\text { types and their } \\
\text { mixtures }\end{array}$} & \multicolumn{4}{|c|}{ Wheat crop yield } & \multicolumn{4}{|c|}{ Maize crop yield } \\
\hline & \multirow{2}{*}{\begin{tabular}{|l}
$\begin{array}{l}\text { Grains } \\
\text { yield }\end{array}$ \\
$\left(\mathrm{kg} \mathrm{fed}^{-1}\right)$
\end{tabular}} & \multirow{2}{*}{$\begin{array}{c}1000 \\
\text { grains } \\
\text { weight } \\
\text { (gm) }\end{array}$} & \multirow{2}{*}{$\frac{I}{\stackrel{I}{o}}$} & \multirow{2}{*}{\begin{tabular}{|l}
$\begin{array}{l}\text { Straw } \\
\text { yield }\end{array}$ \\
$\left(\mathrm{kg} \mathrm{fed}^{-1}\right)$
\end{tabular}} & \multirow{2}{*}{\begin{tabular}{|c}
$\begin{array}{c}\text { Grains } \\
\text { yield }\end{array}$ \\
$\left(\mathrm{kg} \mathrm{fed}^{-1}\right)$
\end{tabular}} & \multirow{2}{*}{$\begin{array}{c}100 \\
\text { grains } \\
\text { weight } \\
(\mathrm{gm})\end{array}$} & \multirow{2}{*}{$\frac{I}{\stackrel{I}{0}}$} & \multirow{2}{*}{$\begin{array}{c}\begin{array}{c}\text { Straw } \\
\text { yield }\end{array} \\
\begin{array}{c}(\mathrm{kg} \\
\left.\mathrm{fed}^{-1}\right)\end{array}\end{array}$} \\
\hline & & & & & & & & \\
\hline Control & 1000 & 30.3 & 34.45 & 1903 & 1900 & 40.0 & 49.22 & 1960 \\
\hline Bentonite & 1458 & 39.8 & 37.72 & 2408 & 2795 & 42.73 & 49.16 & 2893 \\
\hline Compost & 1306 & 39.5 & 35.47 & 2376 & 2625 & 41.55 & 48.89 & 2744 \\
\hline Polyacrylamide & 1847 & 43.7 & 44.23 & 2330 & 2870 & 41.90 & 43.25 & 47.21 \\
\hline $\begin{array}{c}\text { Mix of all } \\
(1: 1: 1)\end{array}$ & 1697 & 43.4 & 38.02 & 2298 & 2841 & 41.74 & 45.42 & 3421 \\
\hline
\end{tabular}

Regarding the statistical analysis of soil conditioners on wheat and maize grain yield, data in Table (13) showed that, there are highly significant differences between polyacrylamide and bentonite and between compost and control in increasing the wheat grain yield. Significant differences also were noticed between mix of all and bentonite. Meanwhile, in case of maize crop, it was noticed that, the high significant effects were noticed between different conditioners and control. But there are no significant differences between conditioners themselves. This may be attributed to the residual effect of conditioners that already remained in soil from the previous wheat season.

Respecting deficit irrigation and its effect on wheat and maize grain yield, it was noticed that there are no significant impacts of deficit irrigation on wheat. However, a significant impact was recorded under maize 
yield. This is may be due to increasing temperature in summer season and hence its effect on increasing evapotranspiration in comparison with winter season. But generally, there are no significant differences between (D1,30\%) and (D2,50\%) under both crops. Consequently, applying deficit irrigation to $50 \%$ depletion from available water could achieve the same higher yield and save much water in loamy

Table (13): Statistical analysis of the grain yield of wheat and maize under applying different conditioners and different levels of water depletion.

\begin{tabular}{|c|c|c|c|}
\hline \multicolumn{2}{|c|}{ Wheat } & \multicolumn{2}{c|}{ Maize } \\
\hline Conditioners & $\begin{array}{c}\text { Grain yield } \\
\text { (Ardeb/fed) }\end{array}$ & Conditioners & $\begin{array}{c}\text { Grain yield } \\
\text { (Ardeb/fed) }\end{array}$ \\
\hline Control & 7.957 & Control & 13.5 \\
\hline Bentocide & 12.102 & Bentocide & 20.5 \\
\hline Compost & 10.865 & Compost & 19.5 \\
\hline Polyacrylamide & 14.744 & Polyacrylamide & 20.9 \\
\hline Mix of all & 13.937 & Mix of all & 20.8 \\
\hline F-test & $* *$ & F-test & $* *$ \\
\hline L.S.D 0.05 & 1.5948 & L.S.D 0.05 & 1.7 \\
\hline L.S.D 0.01 & 2.1475 & L.S.D 0.01 & 2.2 \\
\hline $30 \%$ & 12.399 & $30 \%$ & 19.9 \\
\hline $50 \%$ & 12.212 & $50 \%$ & 18.8 \\
\hline $70 \%$ & 11.152 & $70 \%$ & $*$ \\
\hline F-test & ns & F-test & 1.1 \\
\hline L.S.D 0.05 & 1.235 & L.S.D 0.05 & L.S.D 0.01 \\
\hline L.S.D 0.01 & 1.663 & & \\
\hline
\end{tabular}

\subsection{Crop water productivity:}

Data in Fig.1 (A) showed that wheat water productivity values increased significantly as affected by application of natural soil conditioners. Under irrigation at $30 \%$ depletion from available water, the highest values of WP were recorded $1.7 \mathrm{~kg}$ $\mathrm{m}^{-3}$ with treatment polyacrylamide followed by $1.67,1.6$ and $1.45 \mathrm{~kg} \mathrm{~m}^{-3}$ for mix of all, bentonite and compost respectively compared to control $1.03 \mathrm{~kg} \mathrm{~m}^{-3}$. Data also indicated that, values of WP increased under irrigation at $50 \%$ depletion from available water and gave average values $1.53 \mathrm{~kg} \mathrm{~m}^{-3}$ sand soils. These results agree with those obtained by (Husman et al., 2000). They found that wheat grain yield, harvest index and water use efficiency were greater when irrigation was applied at $50 \%$ soil moisture depletion and was reduced at $70 \%$ depletion. 
different treatments, Data in Fig. 1 (B) shows that maize water productivity increased with applying conditioners. Where, under $30 \%$ depletion, maize water productivity increased to $1.7,1.7,1.5$ and $1.3 \mathrm{~kg} \mathrm{~m}^{-3}$ for polyacrylamide, mix of all, bentonite and compost respectively as compared with control $1.0 \mathrm{~kg} \mathrm{~m}^{-3}$. With respect to irrigation depletion and its effect on maize water productivity. Data show that, under the same conditioner, mean value of water productivity under $50 \%$ depletion was $1.54 \mathrm{~kg} \mathrm{~m}^{-3}$ which decreased to $1.39 \mathrm{~kg} \mathrm{~m}^{-3}$ under $70 \%$ depletion passing by $1.44 \mathrm{~kg} \mathrm{~m}^{-3}$ under $50 \%$ depletion from available water. These results were in accordance with those obtained by (Saleh and Ozawa, 2006) and (Karrou et al., 2012).

(A)

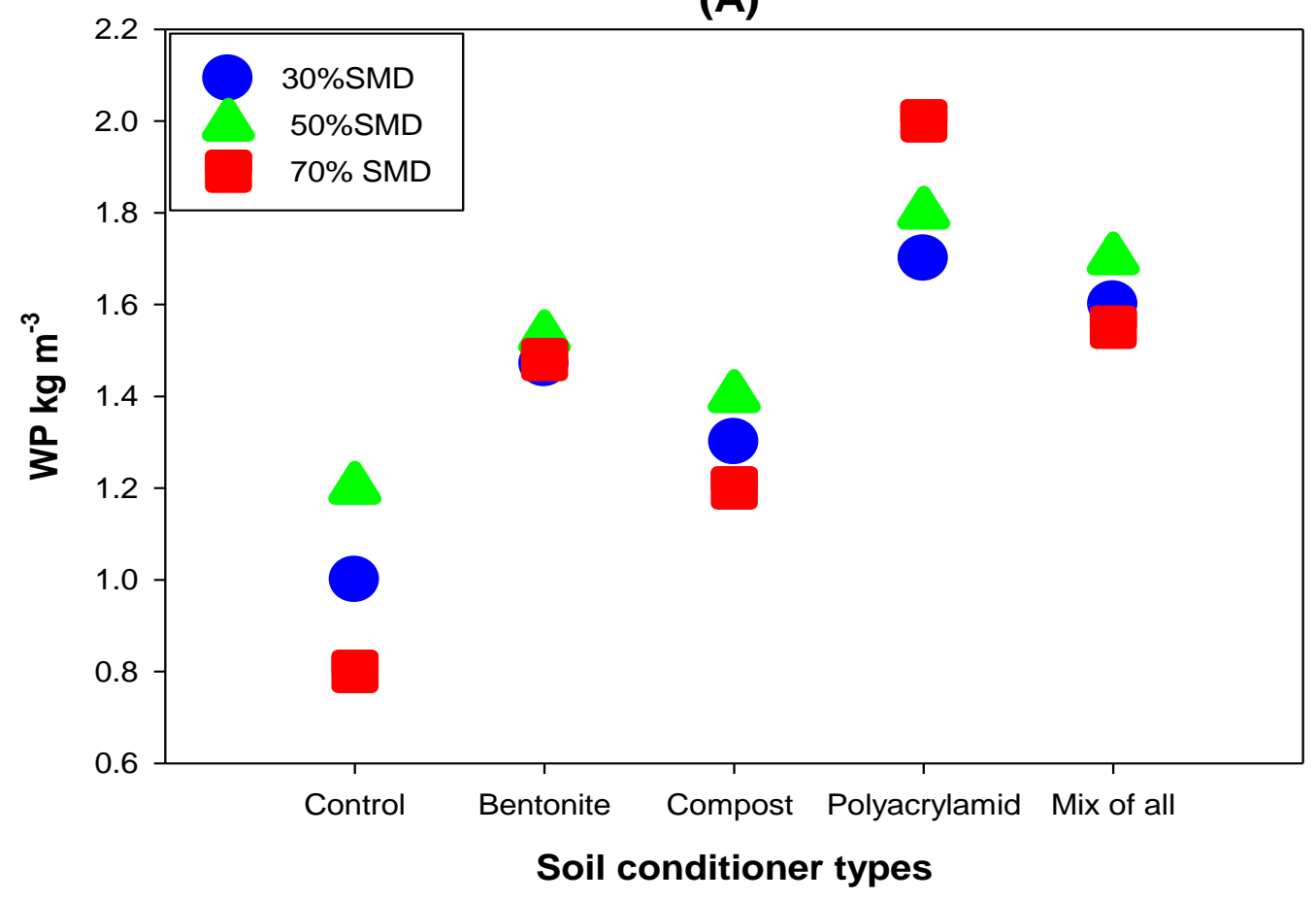


(B)

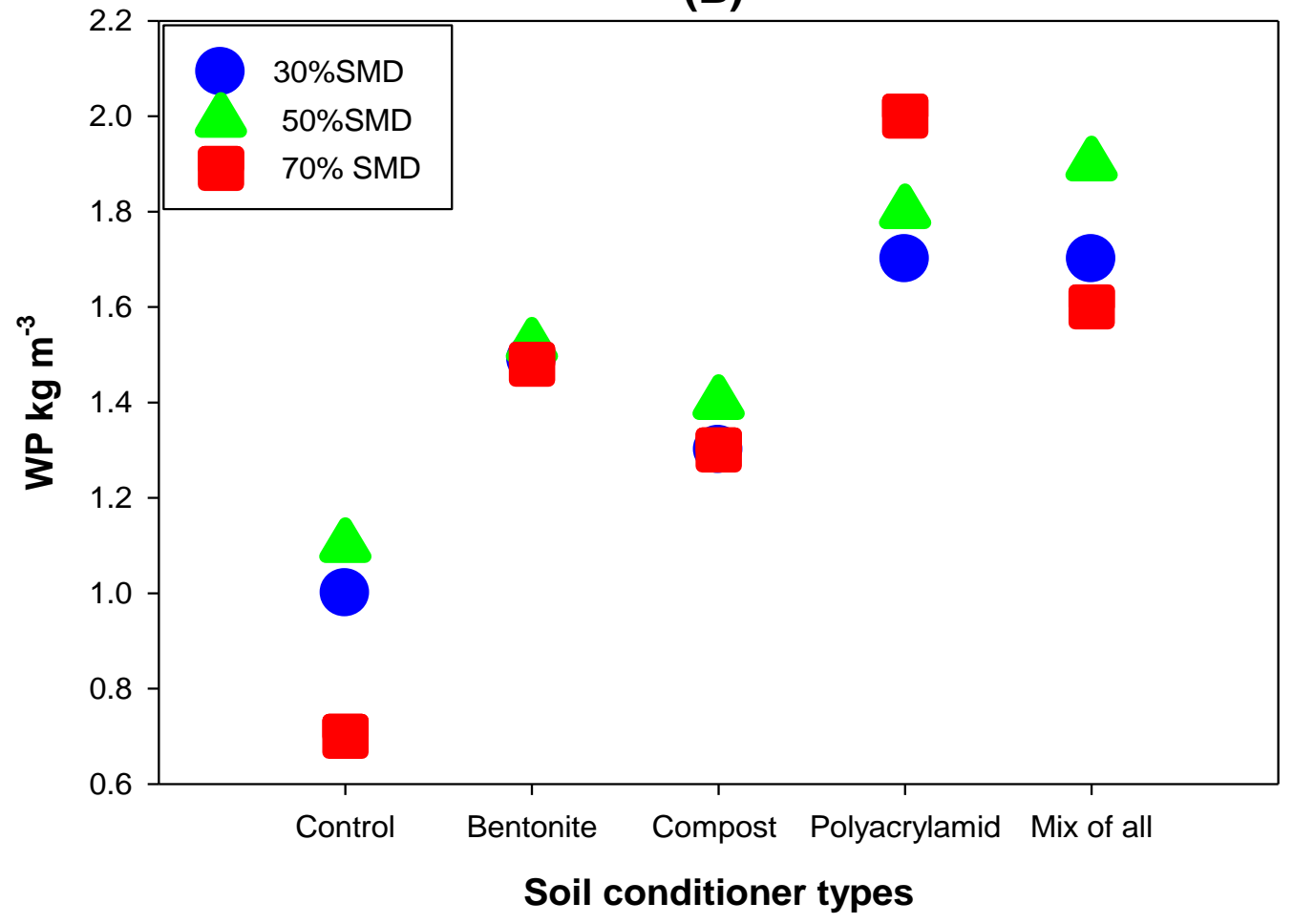

Fig.1. Crop water productivity for wheat (A) and maize (B) subjected to soil conditioners and irrigation regime.

In conclusion, we can deduct that irrigation regime of $50 \%$ depletion from available water which achieved higher values of water productivity saved about 85.7 and $313.2 \mathrm{~m}^{3} \mathrm{fed}^{-1}$ for both wheat and maize crops respectively (Tables 7 and 8 ). Also, polyacrylamide and mix of all conditioners are considered the best conditioners improved soil properties, and crop water productivity under sandy soil conditions.

\section{Conclusion:}

Sandy soils hold little water as the large pore spaces allow water to drain freely from soil. The productivity of these soils is limited by low water holding capacities, high infiltration rates, high evaporation, low inherent fertility levels, very low organic matter content and excessive deep percolation losses. Also, the water use efficiency of the crops cultivated in such soil is low. Therefore, the study was conducted in winter and summer seasons for the main strategic crops (wheat and maize) using different types of soil conditioners under sandy soil conditions. Also, to explore the water use efficiency of both crops under different conditioners, different irrigation regimes as deficit irrigation from available water were used. Conventional conditioner like compost and unconventional conditioners (e.g. bentonite, polyacrylamide and mix of all) were used to explore the outcome variability for each type. The study concluded that polyacrylamide achieved the highest values of crop yield and crop water productivity in response to improving soil physical and chemical properties. Irrigation at $50 \%$ depletion from available water recorded the highest yield and water productivity and saved much water in comparison with 30 and $70 \%$.

\section{REFERENCES}


Abdel-Rheem, H. A. and A. F. Hassan (2011). Reducing of water use by water stress regime on some main field crops (wheat, soybean and corn). J. Soil. Sci . and Agric.Eng.,Mansoura Univ, 2: 635648.

Al-Omran, A. M. and A. R. Al-Harbi (1997). Improvement of sandy soils with soil conditioners. In Handbook of soil conditioners: Substances that enhance the physical properties of soil. (Eds. A.Wallace and R.E.Terry), Marcel Dekker, Inc., New York, 363-384.

Benkhelifa, M., M. Belkhodja, Y. Daoud and D. Tessier (2008) .Effect of Maghnian bentonite on physical properties of sandy soils under semi arid Mediterranean climate. Pak. J. Biol. Sci, 11.

Bouranis, D. L. (1997). Designing synthetic soil conditioners via post polymerization reactions. In Handbook of soil conditioners: Substances that enhance the physical properties of soil. . (Eds. A.Wallace and R.E.Terry), Marcel Dekker, Inc., New York, 333-362.

Burt, R. (2004). "Soil Survey Laboratory Methods Manual". USDA - NRCS, Linoln, Nebraska.

Cottenie, A., P. M. Verloo, L. Kiekens, G. Velghe and R. Camerlynck (1982). "Chemical Analysis of Plant and Soils". Lab.Anal. and Agrochem. State Univ., Gent, Belgium.

De Boodt, M. (1972). Improvement of soil structure by chemical means. In: Optimising the soil physical environment towards greater crop yields. . (Ed. D.Hillel), Academic Press, New York, 4355.

Early, A. C. (1975). Irrigation scheduling for wheat in Punjab. Centosci Prog. Optimum use of water in agriculture, 3 : 115-127.

El-Naka, E. A., K. F. Moussa and A. M. Sayed (2015). Synergistic Effect of Some Soil Amendments on the Physical Properties and Wheat Productivity of Sandy Soils. International Journal of ChemTech Research, 8: 2164-2188.

Garcia (1978). Soil Water Engineering Laboratory Manual. Department of
Agricultural and Chemical Engineering. Colorado State University, Fort Collins, Colorado, USA.

Husman, S. H., M. J. Ottman, R. J. Wegener and M. T. Rogers (2000). Durum response to soil water depletion levels. . Univ. of Arizona, College of Agric and Life Sciences Report, Series P-124. .

IRRI (1998). Using Irristat Software in Statistical Analysis. Manual, Biometrics Unit. Filipinas. .

Israelson, O. W. and V. E. Hansen (1962). Irrigation Principles and Practices (3 rd Ed.). John Willey \& Sons Inc., New York.

Karrou, M., T. OWEIS, R. Abou Eleneen and M. Sherif (2012). Yield and water productivity of maize and wheat under deficit and raised bed irrigation practices in Egypt African Journal of Agricultural Research 7: $1755-1760$.

Khalifa, R. M. (2013). Water requirements of maize and sugar beet crops affected by soil moisture depletion and water table level. M.Sc. Thesis, Soil Sci. Dept. Fac. of Agric., Kafrelsheikh Univ.

Klute, A. (1986). Methods of Soil Analysis, Part 1 (2 nd Ed.): Physical and Mineralogical Methods. ASA, Inc. SSSA, Inc ،. ublisher, Madison, Wisconsin, USA.

Okalebo, J. R., K. W. Gathua and P. L. Woomer (1993). Laboratory Methods of Soil and Plants Analysis: A Working Manual. TSBF Program, Soil Sci. Soc, of East Africa. Technical Publication. No.1, Unesco, Rosta, Kenya.

Omran, W. M. (2005). Maize yield response to available soil moisture. Minufiya $J$. Agric., Res., 30: 1257 - 1268.

Reynolds, W. D. (1993a). Saturated hydraulic conductivity: Laboratory measurement. . Lewis Publishers, Boca Raton, London, Tokyo., In M. R.Carter )ed.): Soil Sampling and Methods of Analysis. Canadian Society of Soil Science, $589-598$.

Reynolds, W. D. (1993b). Saturated hydraulic conductivity: Field measurement. In M. R.Carter (ed.): Soil Sampling and Methods of Analysis. Canadian Society of Soil Science. Lewis 
Publishers, Boca Raton, London, Tokyo., $599-613$.

Saleh, M. I. and K. Ozawa (2006). Improvement of crop yield, soil moisture distribution and water use efficiency in sandy soils by clay application International water Technology Conference, Alexandria ,2006. Egypt.

Saleth, M., A. Inocencio, A. Noble and S. Ruaysoongnern (2009). Economic Gains of Improving Soil Fertility and Water Holding Capacity with Clay Application: The Impact of Soil Remediation Research in Northeast Thailand. IWMI Research Report, 130

http://www.iwmi.cgiar.org/Publications/IW Ml Research R eports/PDF/PUB130/RR130.pdf.

Satje, A. and P. Nelson (2009). Bentonite treatments can improve the nutrient and water holding capacity of sugarcane soils in the wet tropics. Proc. Aust. Soc. Sugar Cane Technol, 31.

Seif, S. A., Allam, S. A. H., M. E. El-Emery and A. E. M. El- Galfy (2005). Effect of soil moisture depletion on growth, yield and yield components of some maize varieties. Annals of Agric.Sci, 43: 25 58.

Silberbush, M., E. Adar and Y. De-Malach (1993). Use of an hydrophilic polymer to improve water storage and availability to crops grown in sand dunes. I. Corn irrigated by trickling. Agricultural Water Management 23: 303-313.

Snedecer, G. W. and W. G. Cochran (1976). Statistical Methods 6th (ed .). lowa State Univ . press, lowa , USA.

Sojka, R. E. and R. D. Lentz (1994). Time for yet another look at soil conditioners. Soil science, 158: 233-234.

Stewart, B. A. (1975). Soil Conditioners. SSSA Spec. Publ. , 7 American Society of Agronomy, Madison, WI, USA.

Tam, K. H. (1993). Principles of Soil Chemistry. Marcel Dekker Inc., New York., 2, 62.

Taylor, K. C. and R. G. Halfacre (1986). The effect of hydrophilic polymer on media water retention and nutrient availability to Ligustrum lucidum. HortScience, 21: 1159-1161.

Van Wambeke, A. (1992). Soils of the Tropics - Properties and Appraisal. McGraw Hill,Inc., New York, USA.

Várallyay, G. Y. (2005). Role of soil multifunctionality in future sustainable agricultural development. Acta Agronomica Academiae Scientiarum Hungaricae, 51: 109-124.

\title{
دراسه فاعليه محسنات التربه والتظام الرطويي علي :
}

\section{1- خواص الاراضي اللوميه الرمليه وانتاجيه المحاصيل وكذلك انتاجيه وحده المياه}

\author{
احمد محمد سعد خير ، محمد عبدالعزيز بيومي، هشام محمود احمد ابوالسعود \\ معهد بحوث الأراضي والمياه والبيئة، محطة البحوث الزراعية بسخا، كفر الثيخ، مصر مبرم
}

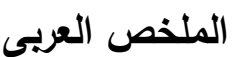

اقيمت تجربتان حقليتان بالاراضي اللوميه الرمليه في مركز بلطيم - كفرالثيخ لزراعه محصولي القمح والذره في موسمين

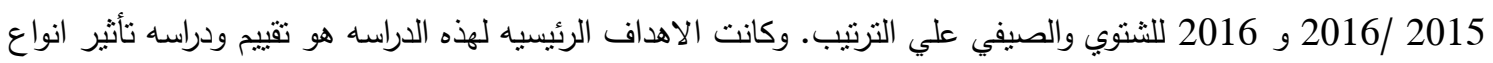

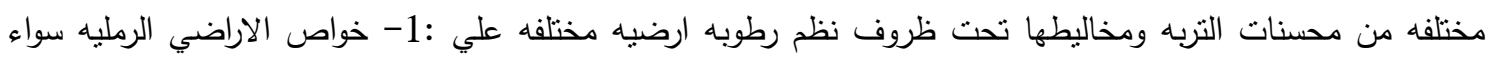

الطبيعيه او الكيميائيه بعد الحصاد ، 2- انتاجيه الاراضي الرمليه من محاصيل الحبوب الرئيسيه (القمح والذره) وكذلك الكي الكيه 


\section{A.M.S. Kheir, et al.,}

لذا تم استخدام اربعه انواع من المحنات الارضيه وهي ( خام البنتونيت ، الكمبوست ، البولي اكريلاميد وكذا مخاليط

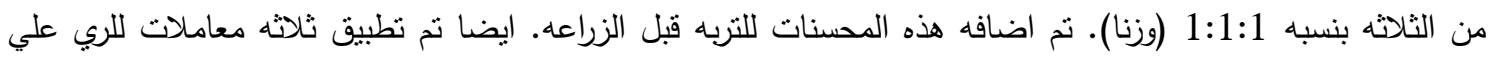

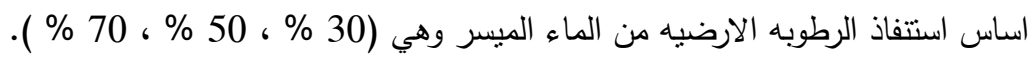
اوضحت النتائج ان اضافه محسنات التربه المختلفه ادي الي تحسين خواص الاراضي الرمليه سواء الكيمبائبه او الطبيعيه

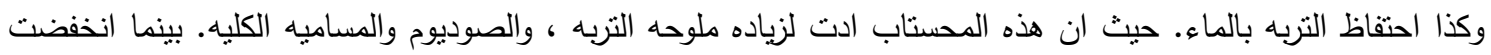

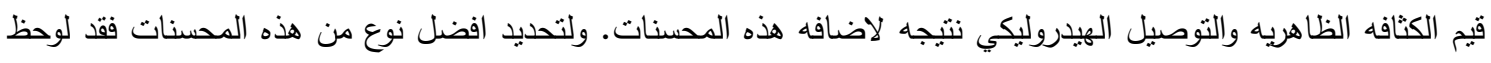

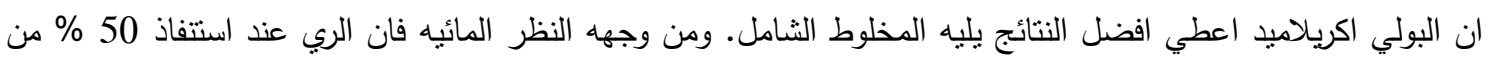
الماء الميسر اعطي افضل القيم لكلا من انتاجيه المحاصيل وكذا انتاجيه وحده المياه من هذه المحاصيل. وبصفه عامه فان

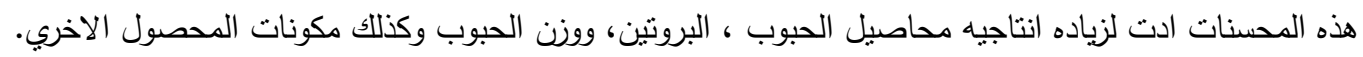

